\title{
Hubungan Perilaku Hidup Bersih Dan Sehat (Phbs) Ibu Dengan Kejadian Diare Pada Balita 0-5 Tahun Di Puskesmas Klasaman Kota Sorong
}

\author{
Helga Ruth Pesireron ${ }^{1}$, I Wayan Badra ${ }^{1}$ \\ ${ }^{1}$ Jurusan Keperawatan Politeknik Kesehatan Sorong \\ Email: wayanbadra@gmail.com
}

\begin{abstract}
The Relationship Between Clean and Healthy Life Behavior (PHBS) with Diarrhea in Toddlers (0-5 Years) in the Work Area of the Sorong City Klasaman Health Center. According to the Indonesian Ministry of Health (2011) One application of PHBS in the household setting that can prevent the occurrence of diarrhea is the Handwashing with Soap (CTPS) behavior. CTPS is one of the pillars of the Community Based Total Sanitation (STBM) strategy, which is contained in the Decree of the Minister of Health of the Republic of Indonesia No. 852 / SK / Menkes / IX / 2008. The importance of CTPS has been understood to reduce the incidence of diarrhea by up to $47 \%$. This is important to be known by the public in order to increase awareness to familiarize CTPS in everyday life. the incidence of diarrhea in children aged 0-5 years in January to March 2017 reached 80 cases (PKM Klasaman, 2017). The purpose of this study was to determine the relationship between Clean and Healthy Behavior (PHBS) with Diarrhea in infants (0-5 years) in the working area of the Sorong City Klasaman Health Center. The research design is a Crossectional Study, the sample uses a total population of 81 respondents, tested with Chi-Square. The results of the study there is a relationship between the behavior of using clean water with the incidence of diarrhea in children 0-5 years in the Sorong City Klasaman Health Center with a value of $0.002<\alpha=0.05$. There is no relationship between the behavior of using healthy latrines with the incidence of diarrhea in children 0-5 years in the Sorong City Klasaman Health Center, the value of which is $0.253>\alpha=0.05$. There is no relationship between the behavior of using clean water and the incidence of diarrhea in children 0-5 years in the Sorong City Klasaman Health Center, a value of $0.110>\alpha=0.05$.
\end{abstract}

Keywords: (PHBS) and Diarrhea

\begin{abstract}
Abstrak: Hubungan Antara Perilaku Hidup Bersih Dan Sehat (PHBS) dengan Diare Pada Balita (0-5 Tahun) Di Wilayah Kerja Puskesmas Klasaman Kota Sorong. Menurut Kemenkes RI (2011) Salah satu penerapan PHBS dalam tatanan rumah tangga yang dapat mencegah terjadinya diare adalah Perilaku Cuci Tangan Pakai Sabun (CTPS). CTPS merupakan salah satu pilar strategi Sanitasi Total Berbasis Masyarakat (STBM), yang tertuang dalam Surat Keputusan Menteri Kesehatan RI No. 852/SK/Menkes/IX/2008. Pentingnya CTPS telah dipahami dapat menurunkan kejadian diare hingga $47 \%$. Hal ini penting diketahui oleh masyarakat agar dapat meningkatkan kesadaran untuk membiasakan CTPS dalam kehidupan sehari-hari. angka kejadian diare pada anak usia 0-5 tahun di bulan Januari s/d Maret tahun 2017 mencapai 80 kasus (PKM Klasaman, 2017). Tujuan penelitian ini adalah Untuk mengetahui hubungan antara Perilaku Hidup Bersih dan Sehat (PHBS) dengan Diare pada balita (0-5 tahun) di wilayah kerja Puskesmas Klasaman Kota Sorong. Desain penelitian adalah Crossectional Study, sampel menggunakan total populasi sebanyak 81 responden, diuji dengan Chi-Square. Hasil penelitian ada hubungan antara perilaku menggunakan air bersih dengan kejadian diare pada anak 0-5 tahun di Puskesmas Klasaman Kota Sorong dengan nilai menunjukkan $0,002<\alpha=0,05$. Tidak ada hubungan antara perilaku menggunakan jamban sehat dengan kejadian diare pada anak 0-5 tahun di Puskesmas Klasaman Kota Sorong, nilai menunjukan 0,253 $>\alpha=0,05$. Tidak ada hubungan antara perilaku menggunakan air bersih dengan kejadian diare pada anak 0-5 tahun di Puskesmas Klasaman Kota Sorong, nilai $0,110>\alpha=0,05$.
\end{abstract}

Kata kunci : (PHBS) dan Diare 


\section{PENDAHULUAN}

Menurut data Riskesdas (2007) bahwa dari 10 indikator PHBS, terdapat 2 indikator yang berhubungan dengan perilaku hygiene yang dapat menyebabkan diare yaitu perilaku menggunakan air bersih dan kebiasaan mencuci tangan. Data dari Riskesdas tahun 2007 secara Nasional menunjukkan $71,1 \%$ penduduk 10 tahun ke atas berperilaku benar dalam perilaku menggunakan air bersih, tetapi hanya $23,2 \%$ yang mempunyai kebiasaan mencuci tangan yang baik.

Di Indonesia, berdasarkan hasil survey morbiditas yang dilakukan oleh Subdirektorat Diare Departemen Kesehatan dari tahun 20002010 bahwa diare masih merupakan salah satu masalah kesehatan masyarakat, dimana angka kesakitan maupun angka kematian pada bayi dan anak banyak disebabkan oleh diare. Diare merupakan buang air besar dalam bentuk cairan lebih dari tiga kali dalam satu hari. Jumlah kasus diare mencapai dua miliar tiap tahunnya (WHO, 2010).

Menurut Kemenkes RI (2011) Salah satu penerapan PHBS dalam tatanan rumah tangga yang dapat mencegah terjadinya diare adalah Perilaku Cuci Tangan Pakai Sabun (CTPS). CTPS merupakan salah satu pilar strategi Sanitasi Total Berbasis Masyarakat (STBM), yang tertuang dalam Surat Keputusan Menteri Kesehatan RI No. 852/SK/Menkes/IX/2008. Pentingnya CTPS telah dipahami dapat menurunkan kejadian diare hingga $47 \%$. Hal ini penting diketahui oleh masyarakat agar dapat meningkatkan kesadaran untuk membiasakan CTPS dalam kehidupan sehari-hari.

Menurut Samsu Aryanto (2007) ada hubungan antara perilaku mencuci tangan dengan sabun setelah buang air besar ( $p$ value 0,021 ) dengan kejadian diare., sedangkan Vera Elfiatri dkk (2007) kondisi yang berhubungan dengan kejadian diare meliputi penggunaan jamban ( $p$ value 0,000001$)$ dan penggunaan air bersih $(\mathrm{p}$ value 0,0049401 ).

Data Puskesmas Klasaman Kota Sorong, angka kejadian diare pada anak usia 0-5 tahun di bulan Januari s/d Maret tahun 2017 mencapai 80 kasus (PKM Klasaman, 2017). Hasil pengamatan peneliti pada 10 orang anak usia $0-5$ tahun 6 dari 10 anak mempunyai kebiasan tidak mencuci tangan saat makan, sedangkan 4 dari 10 anak mempunyai kebiasaan tidak membuang air besar di jamban.

\section{METODE}

Jenis penelitian ini adalah analitik dengan desain cross sectional, sampel penelitian menggunakan total populasi sebanyak 44 responden. Data dianalisis dengan menggunakan SPSS, Uji statistik menggunakan fisher's exact $\mathrm{t}$ Test.

\section{HASIL PENELITIAN}

Tabel 1.1. Hubungan perilaku menggunakan air bersih dengan kejadian diare di Puskesmas Klasaman Kota Sorong

\begin{tabular}{|c|c|c|c|c|}
\hline \multirow[t]{3}{*}{$\begin{array}{c}\text { Perilaku menggunakan } \\
\text { air bersih }\end{array}$} & \multicolumn{2}{|c|}{ Kejadian diare } & \multirow{3}{*}{\multicolumn{2}{|c|}{ Pvalue }} \\
\hline & \multicolumn{2}{|l|}{$\begin{array}{l}\text { Diare } \\
\text { Total }\end{array}$} & & \\
\hline & $\mathrm{F} \%$ & $\mathrm{~F} \quad \%$ & & \\
\hline Memenuhi syarat & 930,0 & $2170,0 \quad 30$ & 100,0 & 0,002 \\
\hline Tidak memenuhi syarat & 990,0 & $1 \quad 10,0 \quad 10$ & 100,0 & \\
\hline Total & 1845,0 & $2255,0 \quad 40$ & 100,0 & \\
\hline
\end{tabular}

Dari tabel 1.1 bahwa dari 40 responden $(100 \%)$ menunjukkan perilaku ibu dalam menggunakan air bersih yang memenuhi syarat dengan kejadian tidak diare lebih besar 21 responden $(70,0 \%)$, dibandingkan kejadian diare 9 responden $(30,0 \%)$. Sedangkan perilaku ibu dalam menggunakan air bersih yang tidak memenuhi syarat dengan kejadian diare lebih besar 9 respnden $(90,0 \%)$, dibandingkan kejadian tidak diare 1 responden $(10,0 \%)$.

Berdasarkan hasil analisis data 1 sel yang memiliki nilai $<5$ maka uji statistik adalah fisher's exact test didapatkan nilap $\mathrm{p}=0,002<\alpha$ $=0,05$ maka Ha diterima yang artinya ada hubungan antara perilaku menggunakan air bersih dengan kejadian diare pada anak 0-5 tahun di Puskesmas Klasaman Kota Sorong.

1.1. Hubungan perilaku mencuci tangan dengan kejadian diare di Puskesmas Klasaman Kota Sorong

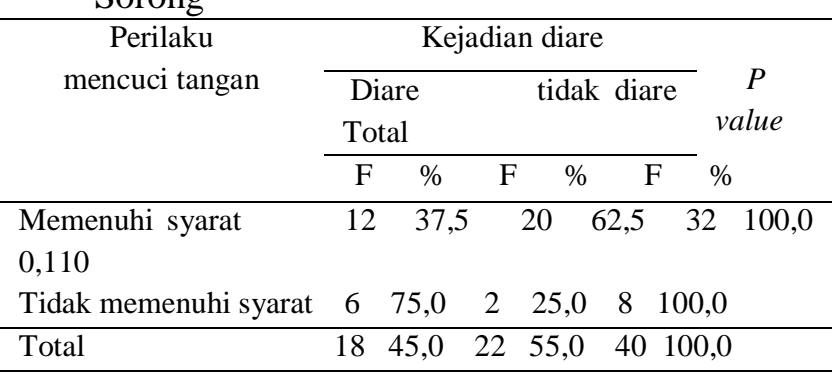


Dari tabel 1.1. Menunjukkan bahwa dari 40 responden $(100 \%)$ menunjukkan perilaku ibu dalam mencuci tangan yang memenuhi syarat dengan kejadian tidak diare lebih besar 20 responden $(62,5 \%)$, dibandingkan kejadian diare 12 responden $(37,5 \%)$. Sedangkan perilaku ibu dalam mencuci tangan yang tidak memenuhi syarat dengan kejadian diare lebih besar 6 responden $(75,0 \%)$, dibandingkan kejadian tidak diare 2 responden $(25,0 \%)$.

Berdasarkan hasil analisis data 2 sel yang memiliki nilai $<5$ maka uji statistik adalah fisher's exact test didapatkan nilap $p=0,110>\alpha$ $=0,05$ maka $\mathrm{H} 0$ diterima yang artinya tidak ada hubungan antara perilaku menggunakan air bersih dengan kejadian diare pada anak 0-5 tahun di Puskesmas Klasaman Kota Sorong.

Tabel 1.2. Hubungan Perilaku Mencuci Tangan Dengan Kejadian Diare Di Puskesmas Klasaman Kota Sorong.

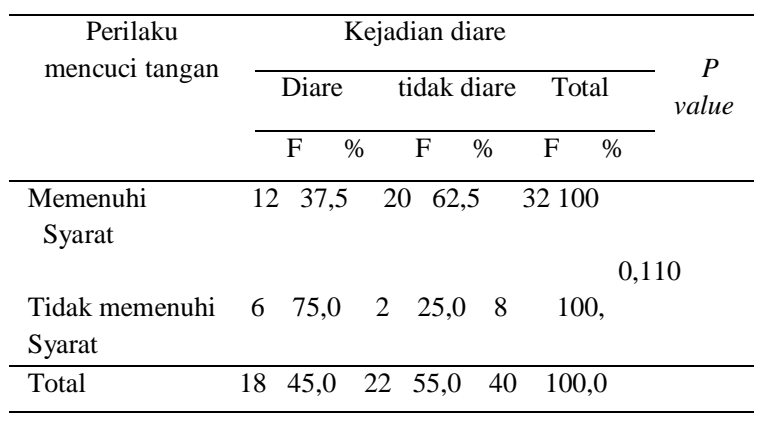

Dari tabel 1.2 bahwa dari 40 responden $(100 \%)$ menunjukkan perilaku ibu dalam mencuci tangan yang memenuhi syarat dengan kejadian tidak diare lebih besar 20 responden (62,5\%), dibandingkan kejadian diare 12 responden $(37,5 \%)$. Sedangkan perilaku ibu dalam mencuci tangan yang tidak memenuhi syarat dengan kejadian diare lebih besar 6 responden $(75,0 \%)$, dibandingkan kejadian tidak diare 2 responden $(25,0 \%)$.

Berdasarkan hasil analisis data 2 sel yang memiliki nilai $<5$ maka uji statistik adalah fisher's exact test didapatkan nilap $p=0,110>\alpha$ $=0,05$ maka $\mathrm{H} 0$ diterima yang artinya tidak ada hubungan antara perilaku menggunakan air bersih dengan kejadian diare pada anak 0-5 tahun di Puskesmas Klasaman Kota Sorong.
Tabel 1.3. Tabulasi silang perilaku menggunakan jamban sehat dengan kejadian diare di Puskesmas Klasaman Kota Sorong

\begin{tabular}{|c|c|c|}
\hline \multirow{3}{*}{$\begin{array}{c}\text { Perilaku } \\
\text { menggunakan } \\
\text { Jamban sehat }\end{array}$} & Kejadian diare & \multirow{3}{*}{$P$ value } \\
\hline & $\begin{array}{lll}\text { Diare } & \text { tidak diare } & \text { Total }\end{array}$ & \\
\hline & $\begin{array}{llllll}\mathrm{F} & \% & \mathrm{~F} & \% & \mathrm{~F} & \%\end{array}$ & \\
\hline Memenuhi syarat & $\begin{array}{llllll}12 & 38,7 & 19 & 61,3 & 31 & 100,0\end{array}$ & 0,253 \\
\hline $\begin{array}{l}\text { Tidak memenuhi } \\
\text { Syarat }\end{array}$ & $\begin{array}{llllll}6 & 66,7 & 3 & 33,3 & 9 & 100,0\end{array}$ & \\
\hline Total & $\begin{array}{llllll}18 & 45,0 & 22 & 55,0 & 40 & 100,0\end{array}$ & \\
\hline
\end{tabular}

Dari tabel 1.3. Dari 40 responden (100\%) menunjukkan perilaku ibu dalam menggunakan jamban sehat yang memenuhi syarat dengan kejadian tidak diare lebih besar 19 responden $(61,3 \%)$, dibandingkan kejadian diare 12 responden $(38,5 \%)$. Sedangkan perilaku ibu dalam menggunakan jamban sehat yang tidak memenuhi syarat dengan kejadian diare lebih besar 6 responden $(66,7 \%)$, dibandingkan kejadian tidak diare 3 responden $(33,3 \%)$.

Berdasarkan hasil analisis data 2 sel yang memiliki nilai $<5$ maka uji statistik adalah fisher's exact test didapatkan nilap $\mathrm{p}=0,253>\alpha$ $=0,05$ maka $\mathrm{H} 0$ diterima yang artinya tidak ada hubungan antara perilaku menggunakan jamban sehat dengan kejadian diare pada anak 0-5 tahun di Puskesmas Klasaman Kota Sorong.

Tabel 1.4. Tabulasi silang perilaku membuang sampah dengan kejadian diare di Puskesmas Kota Sorong.

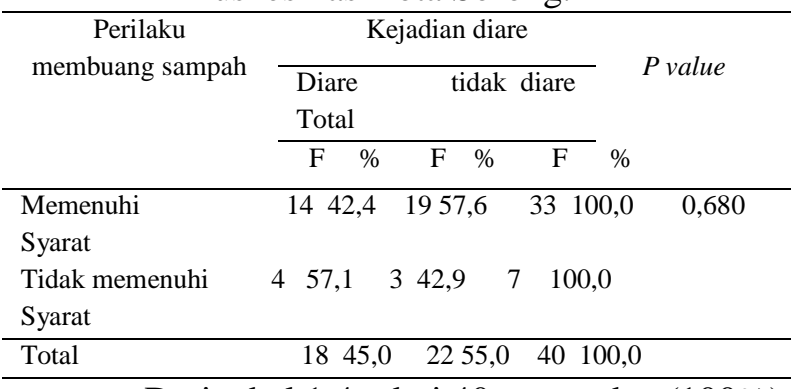

Dari tabel 1.4, dari 40 responden (100\%) menunjukkan perilaku ibu dalam membuang sampah yang memenuhi syarat dengan kejadian tidak diare lebih besar 19 responden $(57,6 \%)$, dibandingkan kejadian diare 14 responden $(42,4 \%)$. Sedangkan perilaku ibu dalam membuang sampah yang tidak memenuhi syarat dengan kejadian diare lebih besar 4 responden $(57,1 \%)$, dibandingkan kejadian tidak diare 3 responden $(42,9 \%)$.

Berdasarkan hasil analisis data 4 sel yang memiliki nilai $<5$ maka uji statistik adalah fisher's exact test didapatkan nilap $p=0,680>\alpha$ $=0,05$ maka $\mathrm{H} 0$ diterima yang artinya tidak ada hubungan antara perilaku membuang sampah 
dengan kejadian diare pada anak 0-5 tahun di Puskesmas Klasaman Kota Sorong.

\section{PEMBaHASAN}

1. Hubungan antara perilaku menggunakan air bersih dengan kejadian diare pada anak 0-5 tahun di Puskesmas Klasaman Kota Sorong.

Berdasarkan hasil analisis data 1 sel yang memiliki nilai $<5$ maka uji statistik adalah fisher's exact test didapatkan nilap $\mathrm{p}=$ $0,002<\alpha=0,05$ maka Ha diterima yang artinya ada hubungan antara perilaku menggunakan air bersih dengan kejadian diare pada anak 0-5 tahun di Puskesmas Klasaman Kota Sorong.

Hal ini disebabkan 10 responden $(25,0 \%)$ tidak memiliki perilaku menggunakan air bersih yang memenuhi syarat yaitu memasak air minum sampai mendidih, menyimpan air di tempat penampungan air yang tertutup, serta membersihkan tempat penampungan air.

Menurut Dinkes Propinsi Jawa Tengah (2006) yang dimaksud perilaku menggunakan air bersih yang sesuai dengan perilaku hidup bersih dan sehat adalah menggunakan/memanfaatkan air bersih untuk keperluan sehari-hari. Air bersih untuk minum (sudah dimasak sampai mendidih, air minum dalam kemasan) membersihkan tempat penampungan air dan menutup tempat penampungan air.

Menurut pengamatan peneliti Jika dilihat dari usia ibu yang mayoritas berkisar antara 20 - 35 tahun, ibu termasuk dalam kategori usia muda (ibu muda), umur dapat mempengaruhi pengetahuan, sikap, dan perilaku (Notoadmojo, 2007) sehingga kesimpulan peneliti bahwa perilaku ibu dalam menggunakan air bersih yang tidak memenuhi syarat dipengaruhi oleh umur.

Hasil penelitian ini sejalan dengan penelitian yang dilakukan oleh Kusumasai (2015) menunjukan ada hubungan antara perilaku menggunakan air bersih dengan kejadian diare di desa Pulosari Kecamatan Kebakramat Kabupaten Karanganyar.

Menurut Depkes RI (2002) yang harus diperhatikan oleh keluarga dalas penggunaan air bersih adalah: a) ambil air dari sumber air bersih, b) ambil dan simpan air dalam tempat yang bersih dan tertutup, c) cuci semua peralatan masak dan makan dengan air bersih yang cukup, d) merebus air minum sampai mendidih.
2. Hubungan antara perilaku mencuci tangan dengan kejadian diare

Berdasarkan hasil analisis data 2 sel yang memiliki nilai $<5$ maka uji statistik adalah fisher's exact test didapatkan nilap $\mathrm{p}=$ $0,110>\alpha=0,05$ maka H0 diterima yang artinya tidak ada hubungan antara perilaku menggunakan air bersih dengan kejadian diare pada anak 0-5 tahun di Puskesmas Klasaman Kota Sorong.

Menurut Depkes RI (2002) kebiasaan yang berhubungan dengan kebersihan perorangan yang penting dalam penularan kuman diare adalah mencuci tangan. Mencuci tangan dengan sabun, terutama sesudah buang air besar, sesudah membuang tinja anak, sebelum menyiapkan makanan, sebelum menyuapi makan anak dan sebelum makan, mempunyai dampak dalam kejadian diare.

Hasil penelitian yang dilakukan oleh Muliawan (2009) menunjukan ada hubungan antara perilaku mencuci tangan dengan kejadian diare di wilayah kerja Puskesmas Kersana Kabupaten Brebes dengan hasil uji statistik dengan menggunakan chi square Test menunjukkan pvalue $=0,003$, sehingga dapat disimpulkan Ha diterima yang artinya ada hubungan antara mencuci tangan dengan kejadian diare.

Hasil pengamatan peneliti bahwa Ibu yang memiliki perilaku mencuci tangan yang baik kemungkinan disebabkan oleh pendidikan yang mayoritas adalah SMA yaitu 15 responden. Pendidikan juga mempengaruhi perilaku yang akan dilakukan ibu tentang PHBS. Menurut penelitian Kusumawati (2008) mengungkapkan bahwa adanya keterikatan antara pendidikan dengan PHBS khususnya dalam perilaku mencuci tangan mempunyai hubungan dengan tingkat kesehatan. Semakin tinggi tingkat pendidikan semakin mudah ibu menerima konsep hidup sehat secara mandiri, kreatif, dan berkesinambungan.

Menurut Harold S. Koplewich (2005) pencegahan diare bisa dilakukan dengan mencuci tangan yang merupakan cara terbaik untuk mencegah infeksi yang menyebar dari orang ke orang. Cuci tangan menjadi cara yang efektif mencegah penularan penyakit sebab kuman yang menempel di tangan menjadi salah satu rantai penularan penyakit. Pada kasus diare misalnya, kuman-kuman diare ikut keluar bersama kotoran/feses dan mudah berpindah tangan saat penderita cebok. Bila sesudahnya tidak mencuci tangan dengan baik, kuman tersebut bisa berpindah ke benda- 
benda yang disentuh termasuk makanan/minuman yang mungkin dikonsumsi juga oleh orang lain (Nadesul Hendrawan, 2008).

3. Hubungan perilaku menggunakan jamban sehat dengan kejadian diare.

Berdasarkan hasil analisis data 2 sel yang memiliki nilai < 5 maka uji statistik adalah fisher's exact test didapatkan nilap $\mathrm{p}=0,253>\alpha=0,05$ maka $\mathrm{H} 0$ diterima yang artinya tidak ada hubungan antara perilaku menggunakan jamban sehat dengan kejadian diare pada anak 0-5 tahun di Puskesmas Klasaman Kota Sorong.

Namun hasil penelitian yang dilakukan oleh F. Jannah (2016) menunjukan ada hubungan antara perilaku menggunakan jamban sehat dengan kejadian diare di Puskesmas Tikala Baru Kota Manado dengan hasil uji statistik dengan menggunakan chi square Test menunjukkan pvalue $=0,002$, sehingga dapat disimpulkan Ha diterima yang artinya ada hubungan antara menggunakan jamban sehat dengan kejadian diare.

Menuret Depkes RI (2002) pengalaman di beberapa Negara membuktikan bahwa upaya penggunaan jamban mempunyai dampak yang besar dalam penurunan resiko terhadap penyakit diare. Pendapat tersebut juga disampaikan oleh Dinkes Propinsi Jawa Tengah (2004) yang menyatakan bila buang air besar tidak di jamban, tinjanya akan dapat menjadi sumber penular bagi orang lain. Kuman pada tinja dapat langsung ditularkan pada orang lain melalui makanan yang tercemar melalui tangan saat memegang atau lewat serangga.

Menurut Dinkes Propinsi Jawa Tengah (2006) yang dimasud perilaku menggunakan jamban sehat yang sesuai dengan perilaku hidup bersih dan sehat pada tatanan rumah tangga adalah anggota rumah tangga menggunakan jamban sehat yang memenuhi syarat kesehatan (leher angsa dengan septictank, cemplung tertutup).

Berdasarkan hasil kuesioner untuk perilaku menggunakan jamban, sebagian besar ibu telah memenuhi syarat, hal ini dilihat dari 31 responden $(100,0 \%)$ telah memenuhi syarat dalam menggunakan jamban sehat yaitu buang air besar di jamban yang terdapat dirumah serta rajin membersihkan jamban. Sedangkan 9 responden $(100,0 \%)$ tidak memenuhi syarat dalam menggunakan jamban sehat. Walaupun sebagain besar ibu telah menerapkan perilaku menggunakan jamban sehat di rumah tetapi tetap saja masih ada ibu yang belum memenuhi syarat dalam perilaku menggunakan jamban sehat. Ini dapat dilihat dari kuesioner bahwa ibu jarang membersihkan jamban.

4. Hubungan perilaku membuang sampah dengan kejadian diare.

Berdasarkan hasil analisis data 4 sel yang memiliki nilai $<5$ maka uji statistik adalah fisher's exact test didapatkan nilap $\mathrm{p}=$ $0,680>\alpha=0,05$ maka H0 diterima yang artinya tidak ada hubungan antara perilaku membuang sampah dengan kejadian diare pada anak 0-5 tahun di Puskesmas Klasaman Kota Sorong. Hal ini disebabkan 33 responden $(100,0 \%)$ telah memenuhi syarat dalam perilaku membuang sampah yaitu membuang sampah di tempat penampungan sampah yang tertutup, dan bila sudah penuh ditutup kembali dengan tanah atau dibakar. Sedangkan 7 responden $(100,0 \%)$ tidak memenuhi syarat dalam menggunakan jamban sehat.

Namun hasil penelitian yang dilakukan oleh W. Ungaran (2011) menunjukan ada hubungan antara perilaku membuang sampah dengan kejadian diare dengan hasil uji statistik dengan menggunakan chi square Test menunjukkan pvalue $=0,000$, sehingga dapat disimpulkan Ha diterima yang artinya ada hubungan antara membuang sampah dengan kejadian diare.

Menurut Dinkes Propinsi Jawa Tengah (2006) yang dimaksud perilaku membuang sampah yang sesuai dengan perilaku hidup bersih dan sehat adalah anggota rumah tangga membuang sampah pada tempatnya. Sampah ditampung dan dibuang setiap hari ditempat pembuangan sampah yang memenuhi syarat kesehatan, serta tidak terdapat sampah yang berserakan baik didalam maupun diluar rumah.

\section{SIMPULAN}

1. Ada hubungan antara perilaku menggunakan air bersih dengan kejadian diare di Puskesmas Klasaman Kota Sorong.

2. Tidak ada hubungan antara perilaku mencuci tangan dengan kejadian diare di Puskesmas Klasaman Kota Sorong.

3. Tidak ada hubungan antara perilaku menggunakan jamban sehat dengan kejadian diare di Puskesmas Klasaman Kota Sorong. 
4. Tidak ada hubungan antara perilaku membuang sampah dengan kejadian diare di Puskesmas Klasaman Kota Sorong.

\section{SARAN}

1. Hasil penelitian ini merupakan masukan bagi pengembangan Ilmu Pengetahuan khususnya "hubungan perilaku hidup bersih sehat (PHBS) ibu dengan kejadian diare pada balita 0-5 tahun di Puskesmas Klasaman Kota Sorong.

2. Sebagai referensi di perpustakaan yang dapat digunakan oleh peneliti lainnya untuk mengembangkan hasil penelitian mereka, dan sebagai sumber Ilmu bagi mereka yang ingin mengetahui dan mempelajari tentang "hubungan perilaku hidup bersih sehat (PHBS) ibu dengan kejadian diare pada balita 0-5 tahun di Puskesmas Klasaman Kota Sorong.

3. Hasil penelitian diharapkan digunakan sebagai masukan bagi profesi keperawatan terkait hubungan perilaku hidup bersih sehat (PHBS) ibu dengan kejadian diare pada balita 0-5 tahun di Puskesmas Klasaman Kota Sorong dan sebagai acuan dalam proses perbaikan program-program kesehatan sehingga menghindari kejadian diare diakibatkan perilaku hidup bersih sehat yang kurang.

4. Sebagai data kepustakaan atau sebagai acuan bagi peneliti selanjutnya sehingga dapat memberikan gambaran tentang hubungan perilaku hidup bersih dan sehat terhadap kejadian diare.

\section{DAFTAR PUSTAKA}

Badan Penelitian dan Pengembangan Kesehatan Kementrian Kesehatan RI.

Riset Kesehatan dasar (RISKESDAS) 2007 [internet]. Available from: http://www.dinkek.go.id

Departemen Kesehatan RI. 2007. Buku Saku Rumah Tangga Sehat dengan PHBS, Pusat Promosi Kesehatan. Jakarta: Depkes RI .
Depkes RI. 2002. Pusat Promosi Kesehatan Pencapaian PHBS.

Elriatri Vira (2005). Tatalaksana penderita diare.Jakarta : Ditjen \& PL.

Dinas Kesehatan Propinsi Jawa Tengah, 2006, Prosedur Tetap Penanggulangan

Departemen Kesehatan RI. 2007. Rumah Tangga Sehat dengan Perilaku Hidup Bersih dan Sehat. Jakarta: Pusat Promosi Kesehatan Departemen Kesehatan RI.

Departemen Kesehatan RI. 2009. Profil Kesehatan Indonesia 2008. Jakarta:

Hold (2005). New Recommendations For The Use of ORS and Zinc Supplementation for Clinic- Based and Healthcare Workers. USA: MOST The USAID Micronutrient Program.

Wati Kusuma. 2008. Hubungan perilaku hidup bersih dan sehat (PHBS) ibu

Muliawan. 2009. Situasi Diare di Indonesia. Medika Indonesia.

Notoatmodjo, S. 2005. Metodologi Penelitian Kesehatan Edisi Revisi. Jakarta: PT

Program Studi S1 Ilmu Keperawatan STIKES Kusuma Husada. 2015. Surakarta.

Program Studi S1 Ilmu Keperawatan STIKES Kusuma Husada (internet).

dengan kejadian diare pada bayi usia 1-12 bulan di Kelurahan Antigoro

Samsu Ariyanto, 2007, Tangkal www.mediaindonesia.com. Penyakit Dengan PHBS,

World Health Organization. (2010). Diarrhoea Treatment Guidelines Including 